\title{
SPATIAL VARIABILITY OF APPARENT ELECTRICAL CONDUCTIVITY AND SOIL PROPERTIES IN A COFFEE PRODUCTION FIELD
}

\author{
DOMINGOS S. M. VALENTE ${ }^{1}$, DANIEL M. DE QUEIROZ ${ }^{2}$, \\ FRANCISCO DE A. DE C. PINTO ${ }^{3}$, FÁBIO L. SANTOS ${ }^{4}$, NERILSON T. SANTOS ${ }^{5}$
}

\begin{abstract}
Precision agriculture based on the physical and chemical properties of soil requires dense sampling to determine the spatial variability of these properties. This dense sampling is often expensive and time-consuming. One technique used to reduce sample numbers involves defining management zones based on information collected in the field. Some researchers have demonstrated the importance of soil electrical variables in defining management zones. The objective of this study was to evaluate the relationship between the spatial variability of the apparent electrical conductivity and the soil properties in the coffee production of mountain regions. Spatial variability maps were generated using a geostatistical method. Based on the spatial variability results, a correlation analysis, using bivariate Moran's index, was done to evaluate the relationship between the apparent electrical conductivity and soil properties. The maps of potassium $(\mathrm{K})$ and remaining phosphorus (P-rem) were the closest to the spatial variability pattern of the apparent electrical conductivity.
\end{abstract}

KEYWORDS: geostatistical, management zone, sensors.

\section{VARIABILIDADE ESPACIAL DA CONDUTIVIDADE ELÉTRICA APARENTE E DAS PROPRIEDADES DO SOLO EM ÁREA DE PRODUÇÃO DE CAFÉ}

RESUMO: A agricultura de precisão baseada nas propriedades físicas e químicas do solo exige uma amostragem densa para se determinar a variabilidade espacial no campo. Essa amostragem densa, muitas vezes, apresenta custo e tempo consumido elevados. Uma das técnicas para reduzir o número de amostras é definir zonas de manejo em função de informações coletadas no campo. Alguns pesquisadores têm demonstrado a importância desempenhada pelas variáveis elétricas do solo para definir zonas de manejo. Dessa forma, este trabalho teve como objetivo avaliar a relação entre a variabilidade espacial da condutividade elétrica aparente e as propriedades do solo em regiões de produção de cafés de montanha. Os mapas de variabilidade espacial foram gerados utilizando-se de técnicas de geoestatística. Com base nos resultados espacializados, foi realizada uma análise de correlação, utilizando-se do índice de Moran bivariado, entre o mapa de condutividade elétrica e as propriedades do solo. Observou-se que os mapas de potássio (K) e fósforo remanescente (P-rem) foram os que mais se aproximaram do padrão de variabilidade espacial da condutividade elétrica aparente do solo.

PALAVRAS-CHAVE: geoestatística, zonas de manejo, sensores.

\section{INTRODUCTION}

The variable-rate application of fertilizer requires dense sampling to determine the spatial variability of field nutrients (SILVA, et al., 2010). High-density soil sampling is often expensive and time-consuming. Reducing the number of samples per hectare can lead to errors in estimations of the spatial variability of soil nutrients, which may cause errors in fertilizer recommendations.

\footnotetext{
${ }^{1}$ Eng $^{\circ}$ Agrícola e Ambiental, Prof. Dr., Departamento de Engenharia Agrícola, Viçosa-MG, Fone: (31) 3899-1876, valente@ufv.br

${ }^{2}$ Eng $^{\mathrm{o}}$ Agrícola, Prof. Doutor, Departamento de Engenharia Agrícola, Viçosa-MG, queiroz@ufv.br

${ }^{3}$ Eng $^{\circ}$ Agrícola, Prof. Doutor, Departamento de Engenharia Agrícola, Viçosa-MG, facpinto@ufv.br

${ }^{4}$ Eng $^{\circ}$ Agrícola, Prof. Doutor, Departamento de Engenharia Agrícola, Viçosa-MG, fabio.ls@ufv.br

${ }^{5}$ Eng $^{\circ}$ Agrônomo, Prof. Doutor, Departamento de Estatística, Viçosa-MG, nsantos@ufv.br

Recebido pelo Conselho Editorial em: 05-2-2013

Aprovado pelo Conselho Editorial em: 20-5-2014
}

Eng. Agríc., Jaboticabal, v.34, n.6, p. 1224-1233, nov./dez. 2014 
One technique used to reduce the number of sample involves defining management zones (XIN-ZHONG et al., 2009). A management zone is an area that has similar characteristics related to the factors that limit crop yield and/or product quality. These zones can then be treated with the same input dosage. Furthermore, when referring to coffee production systems in mountainous areas, the delimitation of management zones is important because it facilitates fertilizer applications at variable rates.

The field information used to delimit management zones is generally based on digital elevation models, soil fertility maps obtained by systematic sampling, apparent soil electrical conductivity maps, soil organic matter maps estimated by remote sensing and crop yield maps obtained over more than one season (FLEMING et al., 2004).

Some researchers (CORWIN \& LESCH, 2003; LESCH et al., 2005; MORAL, et al., 2010; MOLIN \& RABELLO, 2011; SAEY et al., 2009; YAN et al., 2007; YAN et al., 2008) have demonstrated the importance of the electrical soil properties in explaining the variability of the soil's physical and chemical properties and crop yields. The apparent soil electrical conductivity has become one of the most common tools for characterizing the spatial variability of a field because it is reliable and easy to measure (CORWIN \& LESCH, 2003). Therefore, the objective of this study was to evaluate the relationship between the spatial variability of the apparent electrical conductivity and other soil properties of a coffee production field located in a mountainous area.

\section{MATERIALS AND METHODS}

The apparent soil electrical conductivity was measured from July, 07 to 09, 2009 on a coffee farm located in Araponga, State of Minas Gerais, Brazil in an area of coffee plantation of 20.2 ha. In this area Coffea arabica L. species are cultivated. The average elevation is $904 \mathrm{~m}$. The farm is located in a mountainous area, and the soil is classified as Typic Hapludox (SOIL SURVEY STAFF, 2006). The coffee fields are not uniform, as coffee varieties and plant ages may change. According to the Brazilian soil classification the soil is classified as Latossolo Vermelho Amarelo.

The portable sensor LandMapper (Landviser,ERM-02, Houston, USA) was used to determine the apparent soil electrical conductivity. Two Wenner array configurations were used. One configuration had an electrode spacing of $0.20 \mathrm{~m}$ (CE20) to measure the depth at $0-0.20 \mathrm{~m}$ and the other configuration had an electrode spacing of $0.40 \mathrm{~m}$ (CE40) to measure the depth at $0-0.40 \mathrm{~m}$ (CORWIN \& LESCH, 2003). The apparent electrical conductivities and soil properties were determined and the CE20 and CE40 were measured, and soil samples were taken at the 141 points shown in Figure 1.

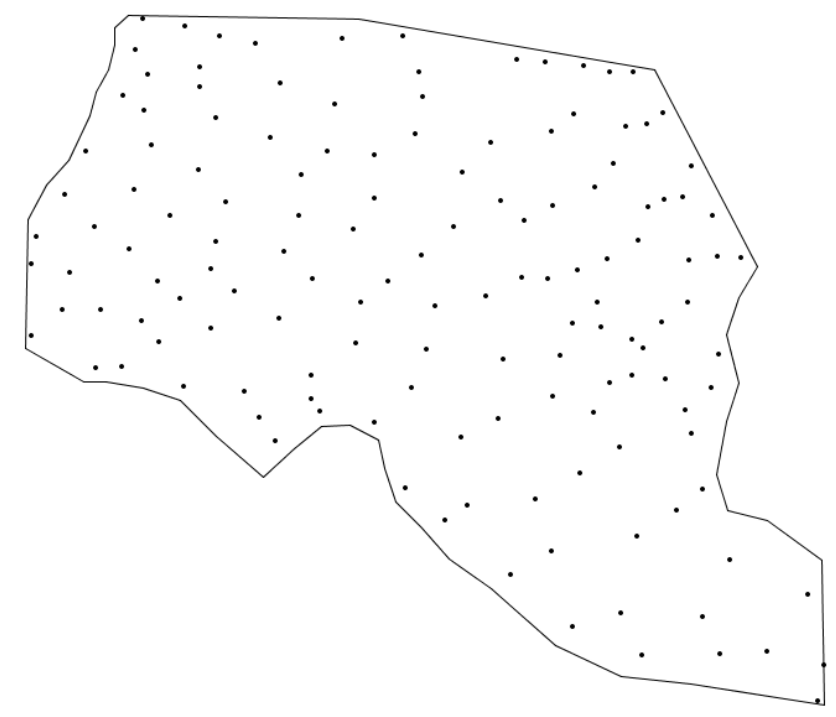

Datum: SAD69 UTM FUSO 23S

FIGURE 1 - Point locations for measuring apparent soil electrical conductivities and soil samples. 
The soil was sampled in the canopy projection of the plant and depth of $0-0.20 \mathrm{~m}$ in an irregular mesh with 141 points (SILVA et al., 2010). Each soil sample comprised three individual samples that were randomly collected in a radius of $1.0 \mathrm{~m}$ around the sampling point. The soil samples were analyzed to obtain the following properties: textural composition (clay, silt and sand content), electrical conductivity of the saturation extract (1:5) and moisture and soil fertility (pH, potential acidity, levels of phosphorous $(\mathrm{P})$, potassium $\left(\mathrm{K}^{+}\right)$, calcium $\left(\mathrm{Ca}^{+2}\right)$, magnesium $\left(\mathrm{Mg}^{+2}\right)$, aluminum $\left(\mathrm{Al}^{+3}\right)$, aluminum-hydrogen $(\mathrm{Al}-\mathrm{H})$, sum of bases, effective cation exchange capacity, cation exchange capacity at $\mathrm{pH} 7.0$, base saturation, $\mathrm{Al}^{+3}$ saturation, remaining $\mathrm{P}$, zinc (Zn), iron $(\mathrm{Fe})$, manganese $(\mathrm{Mn})$, copper $(\mathrm{Cu})$ and organic matter). The sand, silt, and clay fractions were determined by granulometric analysis using the pipette method (Embrapa, 1997). To determine $\mathrm{pH}$, water was used at a 1:2.5 soil/solution ratio. The levels of $\mathrm{P}$ and $\mathrm{K}^{+}$content in the soil were determined using Mehlich1 extractor and the $\mathrm{Ca}^{2+}, \mathrm{Mg}^{2+}$, and $\mathrm{Al}^{3+}$ content were obtained by $\mathrm{KCl}$ extractor $\left(1 \mathrm{~mol} \mathrm{~L}^{-1}\right)$. The Walkley-Black method (organic $\mathrm{C} \times 1.724$ ) was used to determine OM. P-rem was determined using a $\mathrm{CaCl}^{2}$ solution $\left(10 \mathrm{mmol} \mathrm{L}^{-1}\right)$ containing $60 \mathrm{mg} \mathrm{L}^{-1}$ of $\mathrm{P}$. The potential acidity was determined by extraction with $0.5 \mathrm{~mol} \mathrm{~L}^{-1}$ calcium acetate at $\mathrm{pH} 7.0$; the values of $\mathrm{CEC}$ at $\mathrm{pH} 7.0, \mathrm{SB}$, and $\mathrm{V}$ were calculated using classical equations according to Embrapa (1997).

The sampling point locations were obtained using a ProMark3 Topographical GPS (Magellan, Taiwan). For differential post-processing corrections, data were collected from a Brazilian Network for Continuous Monitoring of GPS (RBMC) base station located at the Federal University of Viçosa, Brazil. A post-processed differential correction was performed using GNSS Solutions ${ }^{\circledR}$ software provided by the GPS device manufacturer. Raster maps were obtained by kriging using the Krig-me software (VALENTE et al., 2012).

The spatial correlation analysis was performed using the free and open source GeoDA software (ANSELIN et al., 2005). The global bivariate Moran's index and local bivariate Moran's index was calculated between the apparent electrical conductivities (depth of 0-0.20 meters) and the soil property raster maps. These bivariate Moran's index were also obtained for the apparent soil electrical conductivities (depth of 0-0.40 m) and elevation map. Bivarite Moran's index was used to represent the degree of the spatial correlation between two different spatial variables correlated. First was calculated the global bivariate Moran's index to analyzed general correlation. The second analyze was obtained by local bivariate Moran's index that was visualized in the form of cluster maps. The pseudo-significance level of bivarite Moran's index was tested using the conditional randomization (999 permutations) approach based on the Monte Carlo method. The cluster map was divided into four classes: high-high and low-low cluster (positive spatial correlations) and high-low and low-high (negative spatial correlations) (ANSELIN et al., 2005).

\section{RESULTS AND DISCUSSION}

The results of the semivariance analysis of all soil properties and apparent soil electrical conductivities are shown in Table 1. This result demonstrates in Table 1 that, in general, the $40 \mathrm{~m}$ sampling grid was sufficiently dense to extract the spatial dependence of the apparent soil electrical conductivity and soil properties. The lowest range was $49.64 \mathrm{~m}$ and was obtained using the soil $\mathrm{Ca}^{+2}$ content. The range values for the CE20 and CE40 were $230.25 \mathrm{~m}$ and $177.22 \mathrm{~m}$, respectively. The CE20 and CE40 range values are close to the $149.5 \mathrm{~m}$ range obtained by YAN et al. (2008). The CE20 spatial dependence index (IDE) of $45.80 \%$ was lower than that of the CE40, which was 52.20\%. MOLIN \& CASTRO (2008) determined apparent soil electrical conductivity IDEs of 72\% and $74 \%$. The IDE was lower in this study probably because were obtained lower density of samples than obtained by MOLIN \& CASTRO (2008), who collected one sample per second. 
TABLE 1. Semivariance models obtained for elevation, apparent soil electrical conductivity and soil physical and chemical properties

\begin{tabular}{|c|c|c|c|c|c|c|}
\hline Variable & Model $^{13}$ & $\begin{array}{l}\text { Range } \\
\text { (A) }\end{array}$ & $\begin{array}{c}\text { Sill } \\
(\mathrm{C} 0+\mathrm{C})\end{array}$ & $\begin{array}{l}\text { Nugget Effect } \\
\text { (C0) }\end{array}$ & $\begin{array}{c}\text { IDE } \\
(\mathrm{C} /(\mathrm{C} 0+\mathrm{C}))\end{array}$ & SQR \\
\hline Elevation & GAU & 338.27 & 1818.89 & 21.60 & 0.9880 & 105322.32 \\
\hline $\mathrm{CE} 20^{1}\left(\mathrm{mS}^{-1} \mathrm{~m}^{-1}\right)$ & $\mathrm{SPH}$ & 230.25 & 0.8330 & 0.4511 & 0.4580 & $5.10 \mathrm{E}-2$ \\
\hline $\mathrm{CE} 40^{2}\left(\mathrm{mS} \cdot \mathrm{m}^{-1}\right)$ & LWS & 177.22 & 0.3130 & 0.1496 & 0.5220 & $9.30 \mathrm{E}-3$ \\
\hline $\mathrm{MC}^{3}\left(\mathrm{~kg} \cdot \mathrm{kg}^{-1}\right)$ & GAU & 193.44 & $1.60 \mathrm{E}-3$ & $5.00 \mathrm{E}-4$ & 0.7070 & $1.00 \mathrm{E}-6$ \\
\hline $\mathrm{pH}$ & GAU & 68.59 & 0.2400 & 0.1600 & 0.3340 & 3.04 E-3 \\
\hline $\mathrm{P}\left(\mathrm{mg} \cdot \mathrm{dm}^{-3}\right)$ & EXP & 336.44 & 8.12 & 1.96 & 0.7590 & 19.86 \\
\hline $\mathrm{K}^{+}\left(\mathrm{mg} \cdot \mathrm{dm}^{-3}\right)$ & EXP & 346.91 & 1089.90 & 352.32 & 0.6770 & 25639.92 \\
\hline $\mathrm{Ca}^{2+}\left(\mathrm{cmol}_{\mathrm{c}} \cdot \mathrm{dm}^{-3}\right)$ & GAU & 49.64 & 14.444 & 0.7443 & 0.4850 & 7.30 E-2 \\
\hline $\mathrm{Mg}^{2+}\left(\mathrm{cmol}_{\mathrm{c}} \cdot \mathrm{dm}^{-3}\right)$ & GAU & 975.89 & 0.4795 & 0.1598 & 0.6670 & $2.51 \mathrm{E}-2$ \\
\hline $\mathrm{Al}^{+3}\left(\mathrm{cmol}_{\mathrm{c}} \cdot \mathrm{dm}^{-3}\right)$ & GAU & 988.74 & 0.1406 & 0.0557 & 0.6040 & $2.02 \mathrm{E}-3$ \\
\hline $\mathrm{H}+\mathrm{Al}^{4}\left(\mathrm{cmol}_{\mathrm{c}} \cdot \mathrm{dm}^{-3}\right)$ & EXP & 77.32 & 6.13 & 1.67 & 0.7270 & 17.309 \\
\hline $\mathrm{SB}^{5}\left(\mathrm{cmol}_{\mathrm{c}} \cdot \mathrm{dm}^{-3}\right)$ & GAU & 1020.73 & 4.53 & 2.19 & 0.5170 & 1.65 \\
\hline $\mathrm{CEC}^{6}\left(\mathrm{cmol}_{\mathrm{c}} \cdot \mathrm{dm}^{-3}\right)$ & GAU & 1092.13 & 3.39 & 1.79 & 0.4730 & 0.67 \\
\hline $\mathrm{CEC} \mathrm{pH} 7^{7}\left(\mathrm{cmol}_{\mathrm{c}} \cdot \mathrm{dm}^{-3}\right)$ & GAU & 168.89 & 3.93 & 2.38 & 0.3940 & 1.87 \\
\hline $\mathrm{V}^{8}(\%)$ & GAU & 1082.02 & 406.10 & 218.00 & 0.4630 & 15300.45 \\
\hline $\mathrm{m}^{9}(\%)$ & GAU & 868.11 & 187.24 & 77.07 & 0.5880 & 3093.59 \\
\hline $\mathrm{OM}^{10}\left(\right.$ dag. $\left.^{-1}{ }^{-1}\right)$ & LWS & 157.59 & 11.087 & 0.4926 & 0.5560 & $9.92 \mathrm{E}-2$ \\
\hline P-rem ${ }^{11}\left(\mathrm{mg.L}^{-1}\right)$ & $\mathrm{SPH}$ & 270.90 & 18.96 & 80.450 & 0.5760 & 32.10 \\
\hline Zn (mg.dm³) & SPH & 352.60 & 1.75 & 0.56 & 0.6820 & 0.10 \\
\hline $\mathrm{Fe}\left(\mathrm{mg} . \mathrm{dm}^{-3}\right)$ & LWS & 362.36 & 312.20 & 67.42 & 0.7840 & 2225.09 \\
\hline $\operatorname{Mn}\left(\mathrm{mg} \cdot \mathrm{dm}^{-3}\right)$ & $\mathrm{SPH}$ & 430.89 & 43.52 & 17.94 & 0.5880 & 139.07 \\
\hline $\mathrm{Cu}\left(\mathrm{mg} \cdot \mathrm{dm}^{-3}\right)$ & SPH & 365.68 & 0.3374 & 0.1578 & 0.5320 & $1.75 \mathrm{E}-3$ \\
\hline CEe1:5 ${ }^{12}\left(\mathrm{mS} . \mathrm{m}^{-1}\right)$ & $\mathrm{SPH}$ & 79.24 & 0.8513 & 0.3067 & 0.6400 & $97.89 \mathrm{E}-3$ \\
\hline Coarse sand (dag.kg ${ }^{-1}$ ) & SPH & 283.74 & 22.05 & 4.28 & 0.8060 & 48.39 \\
\hline Fine sand (dag.kg ${ }^{-1}$ ) & $\mathrm{SPH}$ & 262.90 & 4.01 & 0.63 & 0.8440 & 0.52 \\
\hline Silt (dag. $\left.\mathrm{kg}^{-1}\right)$ & GAU & 205.04 & 4.49 & 2.91 & 0.3530 & 0.45 \\
\hline Clay (dag. $\mathrm{kg}^{-1}$ ) & LWS & 199.59 & 27.56 & 3.84 & 0.8610 & 35.94 \\
\hline
\end{tabular}

${ }^{1 /}$ CE20, Apparent soil electrical conductivity to a $0.20 \mathrm{~m}$ depth $;{ }^{2} /$ CE40, Apparent soil electrical conductivity to a $0.40 \mathrm{~m}$ depth $; 3 /$ MC, Moisture content; ${ }^{4} / \mathrm{H}+\mathrm{AL}$, Potential acidity; ${ }^{5} \mathrm{SB}$, Sum of bases; ${ }^{6} / \mathrm{CEC} \mathrm{t}$, Effective cation exchange capacity ; ${ }^{7} \mathrm{CEC} \mathrm{pH} 7$, Cation exchange capacity at $\mathrm{pH} 7{ }^{8} / \mathrm{V}$, Base saturation ; $9 / \mathrm{m}, \mathrm{Al}^{+3}$ saturation; ${ }^{10} / \mathrm{OM}$, Organic matter; ${ }^{11} / \mathrm{P}$-rem, Remaining phosphorus ; ${ }^{12} /$ CEe1:5, Electrical conductivity of saturation; ${ }^{13} /$ GAU, Gaussian; SPH, Spherical; LWS, Linear with sill; EXP, Exponential.

With semivariance model (Table 1) the spatial variability raster maps was generated using kriging interpolation by Krig-me software (VALENTE et al, 2012). The spatial correlations, using global bivariate Moran's index (I), between the CE20 and soil properties raster maps were calculated (Table 2). Figure 2 present the spatial variability maps of CE20 and some soil properties that have the better global bivariate Moran's index in Table 2. To verify the local spatial correlations, the cluster maps were obtained. In Figure 3 present the cluster maps, to analyzed local correlations, between CE20 and the soil properties present in Figure 2. 
TABLE 2. Ranking of the global bivariate Moran's index for apparent soil electrical conductivity (CE20) and other variables

\begin{tabular}{|c|c|c|c|c|c|}
\hline \multicolumn{3}{|c|}{ Positive correlations ranking } & \multicolumn{3}{|c|}{ Negative correlations ranking } \\
\hline $\begin{array}{l}\text { Absolute } \\
\text { Ranking }\end{array}$ & Variable & 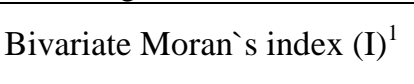 & $\begin{array}{l}\text { Absolute } \\
\text { Ranking }\end{array}$ & Variable & $\begin{array}{l}\text { Bivariate Moran`s } \\
\text { index (I) }\end{array}$ \\
\hline 1 & CE40 (mS.m $\left.{ }^{-1}\right)$ & 0.966 & 1 & $\mathrm{Fe}\left(\mathrm{mg} \cdot \mathrm{dm}^{-3}\right)$ & -0.165 \\
\hline 2 & $\mathrm{~K}^{+}\left(\mathrm{mg} \cdot \mathrm{dm}^{-3}\right)$ & 0.660 & 2 & $\begin{array}{c}\text { Fine sand (dag.kg- } \\
1 \text { ) }\end{array}$ & -0.151 \\
\hline 3 & P-rem (mg. $\left.L^{-1}\right)$ & 0.638 & 3 & m $(\%)$ & -0.141 \\
\hline 4 & $\operatorname{Mn}\left(\mathrm{mg} \cdot \mathrm{dm}^{-3}\right)$ & 0.587 & 4 & OM (dag. $\mathrm{kg}^{-1}$ ) & -0.141 \\
\hline 5 & $\mathrm{P}\left(\mathrm{mg} \cdot \mathrm{dm}^{-3}\right)$ & 0.350 & 5 & Elevation & -0.136 \\
\hline 6 & Zn (mg.dm³) & 0.331 & 6 & $\begin{array}{l}\text { Coarse sand } \\
\left(\text { dag. } \mathrm{kg}^{-1}\right)\end{array}$ & -0.115 \\
\hline 7 & $\operatorname{CEC~}\left(\mathrm{cmol}_{\mathrm{C}} \cdot \mathrm{dm}^{-3}\right)$ & 0.281 & 7 & $\mathrm{pH}$ & -0.059 \\
\hline 8 & Silt (dag.kg ${ }^{-1}$ ) & 0.273 & 8 & $\underset{3}{\mathrm{H}}+\mathrm{Al}\left(\mathrm{cmol}_{\mathrm{c}} \cdot \mathrm{dm}^{-}\right.$ & -0.046 \\
\hline 9 & Cu (mg.dm³) & 0.248 & & & \\
\hline 10 & $\mathrm{SB}\left(\mathrm{cmol}_{\mathrm{c}} \cdot \mathrm{dm}^{-3}\right)$ & 0.236 & & & \\
\hline 11 & $\mathrm{Ca}^{2+}\left(\mathrm{cmol}_{\mathrm{c}} \cdot \mathrm{dm}^{-3}\right)$ & 0.219 & & & \\
\hline 12 & $\mathrm{MC}\left(\mathrm{kg} \cdot \mathrm{kg}^{-1}\right)$ & 0.184 & & & \\
\hline 13 & CEC PH7 $\left(\mathrm{cmol}_{\mathrm{c}} \cdot \mathrm{dm}^{-3}\right)$ & 0.161 & & & \\
\hline 14 & V $(\%)$ & 0.120 & & & \\
\hline 15 & CEe1:5 (mS.m $\left.{ }^{-1}\right)$ & 0.098 & & & \\
\hline 16 & Clay (dag.kg ${ }^{-1}$ ) & 0.075 & & & \\
\hline 17 & $\mathrm{Mg}^{2+}\left(\mathrm{cmol}_{\mathrm{c}} \cdot \mathrm{dm}^{-3}\right)$ & 0.066 & & & \\
\hline 18 & $\mathrm{Al}^{+3}\left(\mathrm{cmol}_{\mathrm{c}} \cdot \mathrm{dm}^{-3}\right)$ & 0.063 & & & \\
\hline
\end{tabular}

${ }^{1}$ Global bivariate Moran's index; pseudo p-value $=0.001$ with 999 permutations 


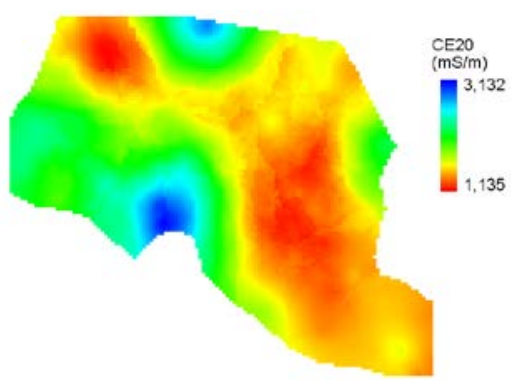

(a) CE20

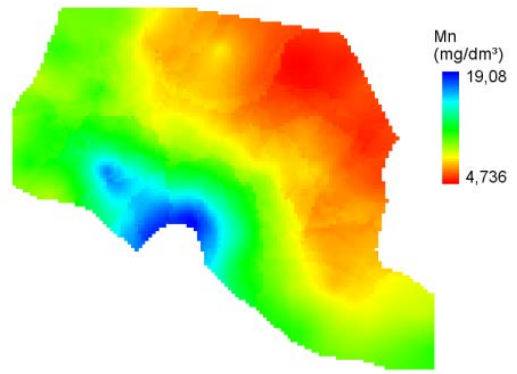

(d) $\mathrm{Mn}$

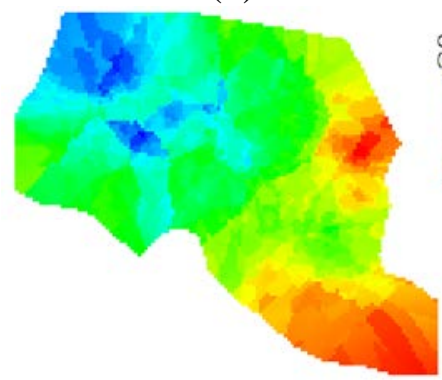

(g) CEC

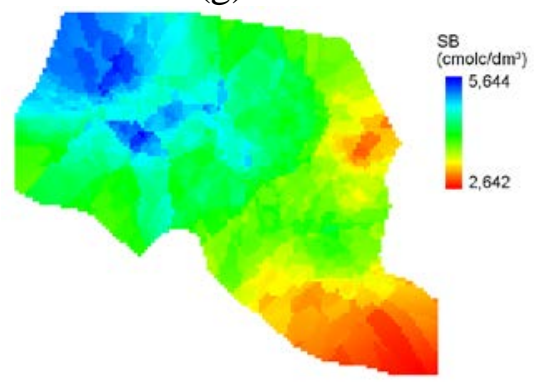

(j) SB

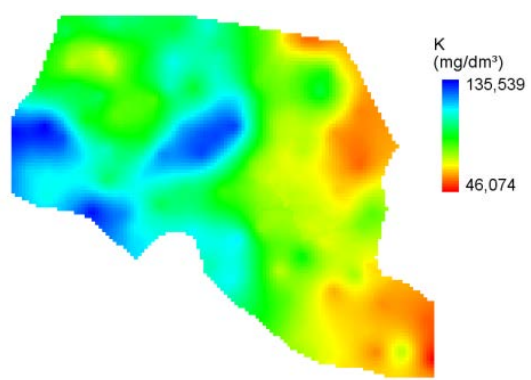

(b) $\mathrm{K}^{+}$

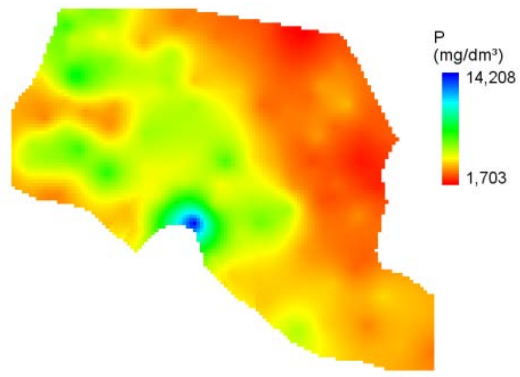

(e) $\mathrm{P}$

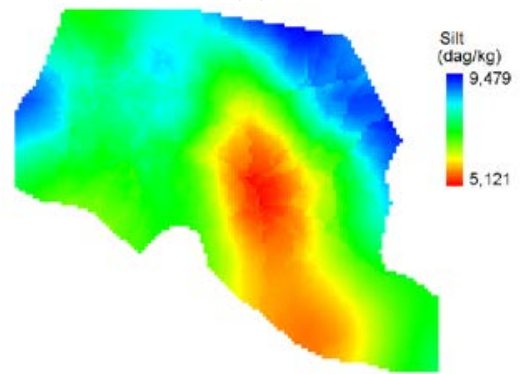

(h) Silt

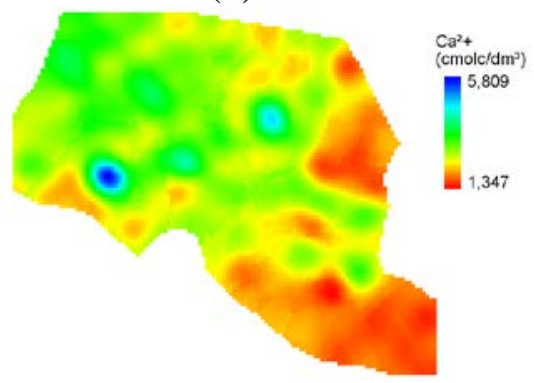

(l) $\mathrm{Ca}^{2+}$

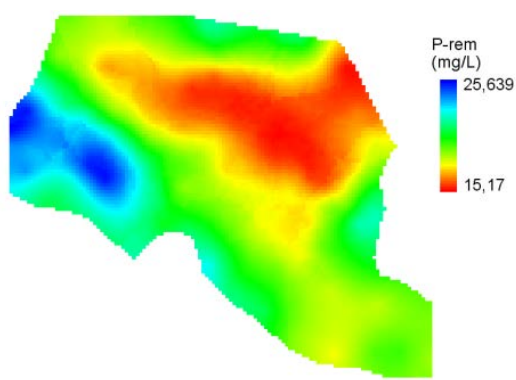

(c) P-rem

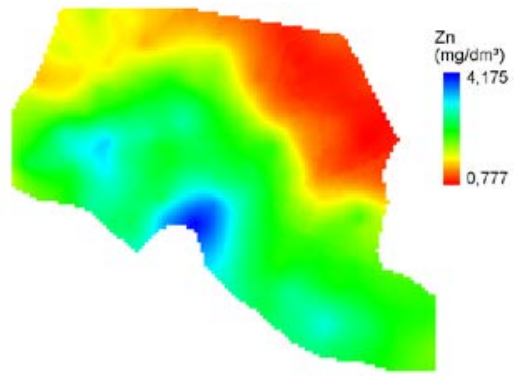

(f) Zn

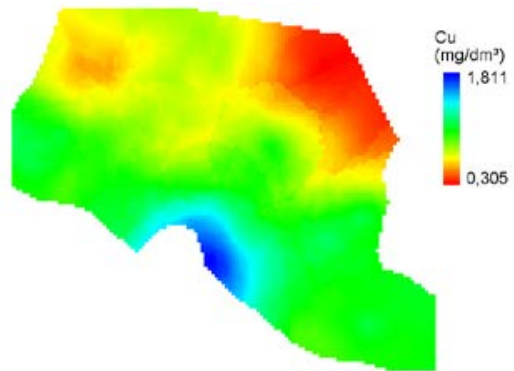

(i) $\mathrm{Cu}$

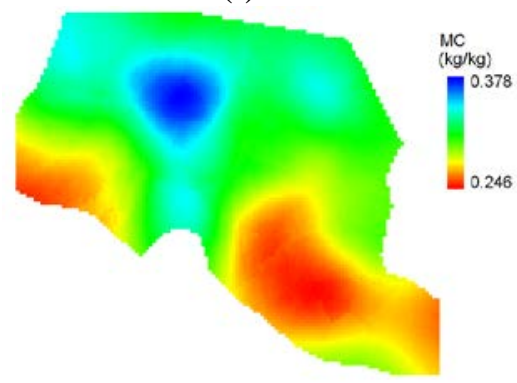

(m) MC

FIGURE 2. Spatial variability maps of (a) apparent soil electrical conductivity to $0.20 \mathrm{~m}$ depth (CE20) and (b) potassium ( $\mathrm{K}^{+}$), (c) remaining phosphorous (P-rem), (d) manganese (Mn), (e) phosphorus (P), (f) zinc (Zn), (g) cation exchange capacity (CEC), (h) silt, (i) copper $(\mathrm{Cu})$, (j) sum of bases, (l) calcium $\left(\mathrm{Ca}^{2+}\right)$ and $(\mathrm{m})$ moisture content (MC). 

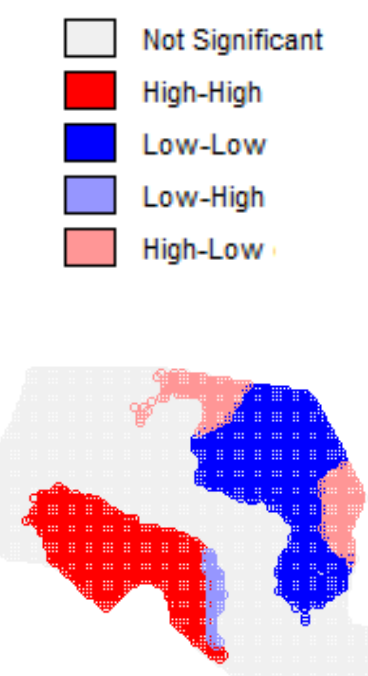

(c) $\mathrm{Mn}$

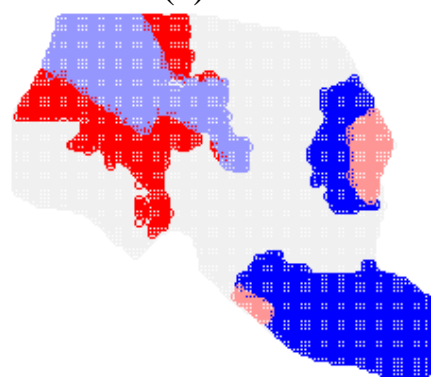

(f) CEC

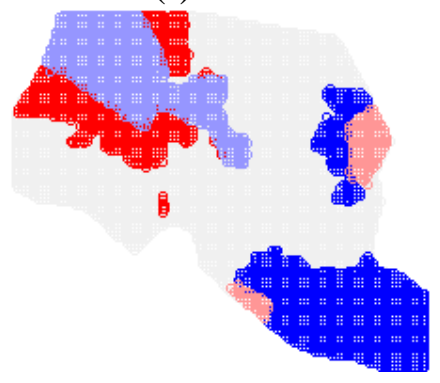

(i) $\mathrm{SB}$

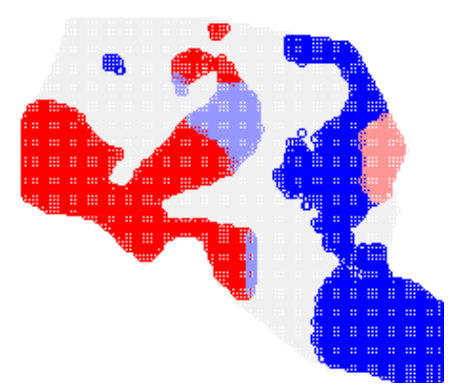

(a) $\mathrm{K}^{+}$

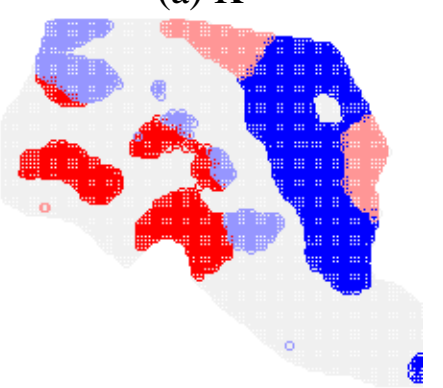

(d) $\mathrm{P}$

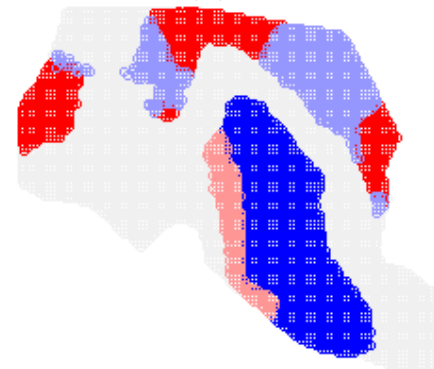

(g) Silt

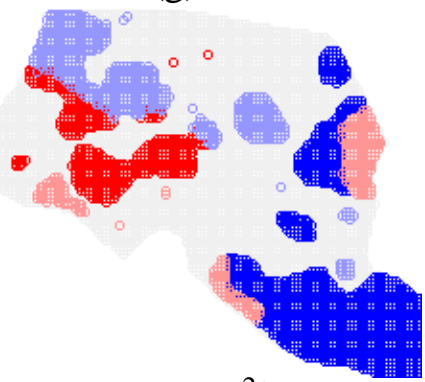

(j) $\mathrm{Ca}^{2+}$

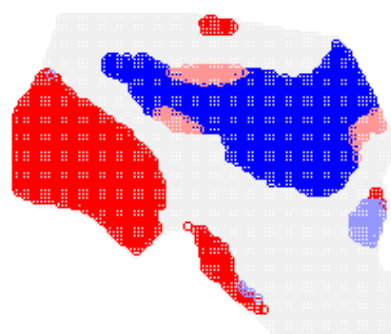

(b) P-rem

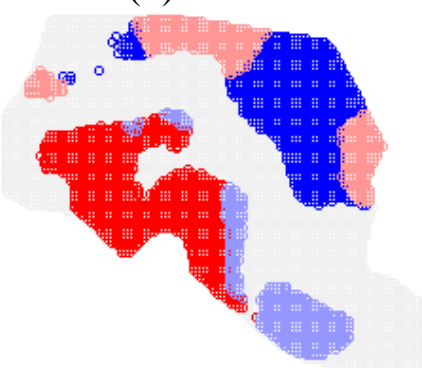

(e) $\mathrm{Zn}$

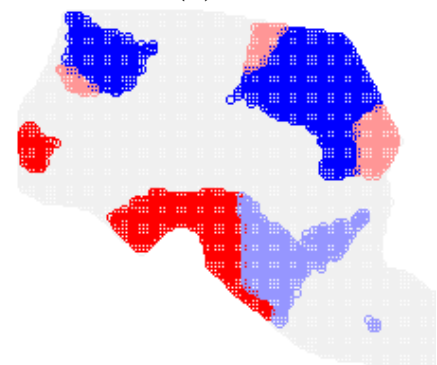

(h) $\mathrm{Cu}$

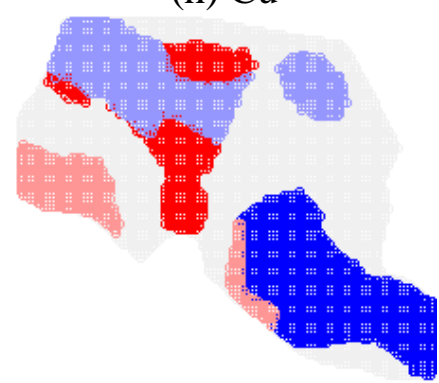

(l) $\mathrm{MC}$

FIGURE 3. Cluster map of the local bivariate Moran's index (pseudo p-value $<0.05$ with 999 permutations) to apparent soil electrical conductivity to $0.20 \mathrm{~m}$ depth (CE20) and (a) potassium $\left(\mathrm{K}^{+}\right)$, (b) remaining phosphorous (P-rem), (c) manganese (Mn), (d) phosphorus (P), (e) zinc (Zn), (f) cation exchange capacity (CEC), (g) silt, (h) copper $(\mathrm{Cu})$, (i) sum of bases, (j) calcium $\left(\mathrm{Ca}^{2+}\right)$ and (l) moisture content (MC).

The CE20 and CE40 maps exhibit strong spatial correlation (Table 2). These similarities were confirmed by analyzing the bivariate Moran's index $(I=0.966)$. Similarities between the spatial variability maps of the apparent electrical conductivity at different depths of the soil were also observed by other researchers (LESH et al. 2005; MOLIN \& CASTRO, 2008; VITHARANA et al., 2008).

A comparison of the CE20 map with the elevation and soil moisture (MC) maps revealed low spatial correlations for both the elevation $(I=-0.136)$ and the soil $M C(I=0.184)$ maps, as shown in Table 2. Despite of low correlations, negative correlations for elevations and positive correlations for MC were expected. It means that, in general, areas with higher CE20 values were found at lower elevations and had high soil MC. In Table 2, we can verify that MC presented better spatial 
correlation than elevation. It is possible to see for MC, as showed in Figure 3 (l), that area with low CE20 and low MC (low-low in Figure 3). The low-low area in Figure 3 (l) is the cluster that indicates the local correlations. To the rest of the area, positive correlations were observed (highhigh), but with outliers clusters (high-low and low-high). The same local correlations can be found for the $\mathrm{K}^{+}$, CEC, SB and $\mathrm{Ca}^{2+}$ (Figure 3). It means that, the low-low cluster map for these soil properties can be manage in the same way and the CE20 can be used to identify then. MOLIN \& RABELLO (2011), in a detailed study using a commercial measuring equipment of apparent soil electrical conductivity, obtained results that indicated apparent soil electrical conductivity relates with soil texture and MC.

The $\mathrm{K}^{+}$levels presented the highest spatial correlation $(\mathrm{I}=0.660)$ with the CE20 among the measured soil properties, as showed in Table 2. The maps in Figure 3 (a) reveal regions with highhigh and low-low cluster. There are low quantities of the high-low and low-high outliers cluster. It means higher spatial correlations and the potential to create management zones. This correlation result agrees with the other results (BEKELE et al., 2005; MOLIN \& CASTRO, 2008). These authors also determined that the correlation coefficient between the electrical conductivity and the $\mathrm{K}^{+}$content was the highest among the measured soil properties. Some authors (SILVA et al. 2002) have highlighted the importance of $\mathrm{K}^{+}$levels to coffee quality. Thus, the apparent soil electrical conductivity could become a useful tool for defining management zones for coffee quality purposes.

The spatial correlation between the P and CE20 maps was raking in fourth position among the soil properties $(\mathrm{I}=0.350)$. The eastern part of the coffee field had the lowest $\mathrm{P}$ content, as shown in Figure 2 (e). In addition, it is possible to verify the low-low cluster between P and CE20 (Figure 3). It is also possible to identify the high-high cluster for P and CE20 in the same region of the highhigh cluster between $\mathrm{K}+$ and CE20. BEKELE et al. (2005) obtained coefficients of correlation between the P contents and apparent soil electrical conductivities that ranged from -0.03 to 0.58 . Other authors found highest and negative correlation between CE20 and P level (MOLIN \& CASTRO, 2008). These results demonstrate that $\mathrm{P}$ concentrations do not correlate with apparent soil electrical conductivity as well as potassium and depend of the soil type. However, the results show the importance of the apparent soil electrical conductivity to define management zones, since potassium and phosphorus are the main macronutrients used in coffee crops.

The Mn, Zn, and Cu micronutrient maps are shown in Figure 2 (d), Figure 2 (f) and Figure 2 (i), respectively, exhibited positive bivariate Moran's index ( $\mathrm{I}=0.587, \mathrm{I}=0.331$ and $\mathrm{I}=0.248$, respectively). The Fe content presented the negative and lowest spatial correlation $(\mathrm{I}=-0.165)$ among micronutrients. In general, the high-high and low-low cluster presented the same pattern for the $\mathrm{Mn}, \mathrm{Zn}$ and $\mathrm{Cu}$. It means the in part of the coffee field had high $\mathrm{Mn}, \mathrm{Zn}$ and $\mathrm{Cu}$ concentrations and also presented high CE20 values. The Mn content map had a spatial variability pattern that was closest to the CE20 map and, among the measured micronutrients, presented the highest spatial correlation with the CE20 map and low outliers cluster (high-low and low-high), as showed in Figure 3.

The spatial correlation between the CE20 and the clay content was near zero $(\mathrm{I}=0.075)$, and the coefficient between the CE20 and the organic matter content was low and negative (I = -0.141). Large positive correlations were expected for organic matter and clay content (MOLIN \& CASTRO, 2008; REIS et al., 2009). However, in the soil classified as Typic Hapludox, recommendations for fertilizer are often carried out according to the remaining $\mathrm{P}$ content because they depend also on the clay quality (SILVA et al., 2010). It could be seen that areas with low Prem levels also tended to have low apparent soil electrical conductivities (low-low cluster), and areas with high P-rem values tended to have high apparent soil electrical conductivities (high-high cluster), as showed in Figure 3 (b). This observation was confirmed by determining the global spatial correlation between these two quantities $(I=0.638)$. These results suggest the apparent soil electrical conductivity is closely linked with the P-rem levels in the study area. 


\section{CONCLUSIONS}

The apparent soil electrical conductivity showed high global and local spatial correlation with the macronutrients potassium and phosphorus and the micronutrients manganese, zinc and copper. The local cluster tend to be stable for most of the soil properties. Despite the lack of spatial correlation with the clay content, the apparent soil electrical conductivity showed a strong correlation with the remaining phosphorus, an important indicator of fertility in the soil. Thus, the apparent soil electrical conductivity showed to be an important tool for defining management zones for precision agriculture.

\section{ACKNOWLEDGEMENTS}

The authors of the this study thank the Foundation for Research Financial Support from the State of Minas Gerais, Brazil (FAPEMIG) and the National Council for Scientific and Technological Development (CNPq) for their financial support of this research.

\section{REFERENCES}

ANSELIN, LUC; SYABRI, IBNU; KHO, YOUNGIHN. GeoDa: An introduction to spatial data analysis. Geographical Analysis, Columbus, v.38, n.1, p.5-22, 2005.

BEKELE, A.; HUDNALL, W.H.; DAIGLE, J.J.; PRUDENTE, J.A.; WOLCOTT, M. Scale dependent variability of soil electrical conductivity by indirect measures of soil properties. Journal of Terramechanics, Oxford, v.42, n.3-4, p.339-351, 2005.

CORWIN, D.L.; S.M. LESCH. Application of soil electrical conductivity to precision agriculture: theory, principles, and guidelines. Agronomy Journal, Madson, v.95, n.3, p.471-471, 2003.

EMBRAPA - Empresa Brasileira de Pesquisa Agropecuária. Manual de métodos de análise de solo. 2.ed. Rio de Janeiro: Centro Nacional de Pesquisa de Solos, 1997. 212p.

FLEMING, K.L.; HEERMANN, D.F., WESTFALL, D.G. Evaluating soil color with farmer input and apparent soil electrical conductivity for management zone delineation. Agronomy Journal, Madson, v.96, n.6, p.1581-1587, 2004.

LESCH, S.M.; CORWIN, D.L.; ROBINSON, D.A. Apparent soil electrical conductivity mapping as an agricultural management tool in arid zone soils. Computer and Electronics in Agriculture, Netherlands, v.46, n. 1-3, p.351-378, 2005.

MOLIN, J.P.; CASTRO, C.N. Establishing management zones using soil electrical conductivity and other soil properties by the fuzzy clustering technique. Scientia Agricola, Piracicaba, v.65, n.6, p.567-573, 2008.

MOLIN, J.P.; RABELLO, L.M. Estudos sobre a mensuração da condutividade elétrica do solo. Engenharia Agrícola, Jaboticabal, v.31, n.1, p.90-101, 2011.

MORAL, F.J.; TERRÓN, J.M.; SILVA, J.R.M. Delineation of management zones using mobile measurements of soil apparent electrical conductivity and multivariate geostatistical techniques. Soil \& Tillage Research, Amsterdam, v.106, n.2, p.335-343, 2010.

REIS, L.R.; VIEIRA, L.B.; MANTOVANI, E.C.; SANTOS, N.T.; QUEIROZ, D.M. Correlation between the electric conductivity and chemical properties of a dark yellow latossolo soil. Engenharia na Agricultura, Viçosa, MG, v.17, n.3, p.227-232, 2009.

SAEY, T.; VAN MEIRVENNE, M.; VERMEERSCH, H.; AMELOOT, N.; COCKX, L. A Pedotransfer function to evaluate the soil profile textural heterogeneity using proximally sensed apparent electrical conductivity. Geoderma, Amsterdam, v.150, n.3-4, p.389-395, 2009.

SILVA, E.B.; NOGUEIRA, F.D.; GUIMARÃES, P.T.G. Potassium fertilization and the quality of processed coffee beans. Scientia Agrícola, Piracicaba, v.59, n.1, p.173-179, 2002. 
SILVA, S.A.; LIMA, J.S.S.; SOUZA, S.S.; OLIVEIRA, R.B.; SILVA, A.F. Variabilidade espacial do fósforo e das frações granulométricas de um Latossolo Vermelho Amarelo. Revista Ciencia Agroronomica, Fortaleza, v. 41, n. 1, p. 1-8, 2010.

SOIL SURVEY STAFF. Keys to Soil Taxonomy. $10^{\text {th }}$ ed. Washington, DC: USDA/NCRS, Washington, 2006.

VALENTE, D.S.M; QUEIROZ, D.M.; PINTO, F.A.C.; SANTOS, N.T.; SANTOS, F.L. Definition of management zones in coffee production fields based on apparent soil electrical conductivity. Scientia Agrícola, Piracicaba, v. 69, p. 173-179, 2012.

VITHARANA, U.W.A.; MEIRVENNE, M.V.; SIMPSON, D.; COCKX, L.; BAERDEMAEKER, J. Key soil and topographic properties to delineate potential management classes for precision agriculture in the European loess area. Geoderma, Amsterdam, v.143, n.1-2, p.206-215, 2008.

XIN-ZHONG, W.; GUO-SHUNA, L.; HONG-CHAO, H.; ZHEN-HAIB, W.; QING-HUAB, L.; XU-FENGC, L.; WEI-HONGC, H.; YAN-TAOC, L. Determination of management zones for a tobacco field based on soil fertility. Computers and Electronics in Agriculture, Netherlands, v.65, n.2, p.168-175, 2009.

YAN, L.; ZHOU, S.; CI-FANG, W.; HONG-YI, L; FANG, L. Determination of potential management zones from soil electrical conductivity, yield and crop data. Journal of Zhejiang University Science B, Hangzhou, v.9, n.1, p.68-76, 2008.

YAN, L.; ZHOU, S.; FENG, L. Delineation of site-specific management zones based on temporal and spatial variability of soil electrical conductivity. Pedosphere, Nanjing, v.17, n.2, p.156-164, 2007. 